Cathcart, A. (2009) The statutes of Iona: the archipelagic context. Journal of British Studies, 49 (1). pp. 4-27. ISSN 0021-9371

http://strathprints.strath.ac.uk/26412/

Strathprints is designed to allow users to access the research output of the University of Strathclyde. Copyright (C) and Moral Rights for the papers on this site are retained by the individual authors and/or other copyright owners. You may not engage in further distribution of the material for any profitmaking activities or any commercial gain. You may freely distribute both the url (http://strathprints.strath.ac.uk) and the content of this paper for research or study, educational, or not-for-profit purposes without prior permission or charge. You may freely distribute the url (http://strathprints.strath.ac.uk) of the Strathprints website.

Any correspondence concerning this service should be sent to The Strathprints Administrator: eprints@cis.strath.ac.uk 


\title{
The Statutes of Iona: The Archipelagic Context
}

\author{
Alison Cathcart
}

I

$\mathrm{n}$ recent decades, understanding of the historical development of Britain and Ireland has benefited significantly from the adoption of integrated approaches to the history of Britain and Ireland. While traditional national histories laid the foundation, the new British and Irish historiography has teased out many of the nuances arising from the interaction between the three kingdoms or four nations of Britain and Ireland. This approach has produced much scholarly work for both the medieval and early modern periods, although modern historians are still grappling with attempts to write a genuinely British history. ${ }^{1}$ For the early modern period in particular, the "three kingdoms" debate of the seventeenth century has advanced awareness of the complexity of regal union and the problems associated with one king ruling three distinct kingdoms. It is within this wider British context that James VI and I's efforts to integrate his three kingdoms need to be viewed. Although James's "earnist dispositioun to perfyte that Union"brought about by his succession to the English throne on 1603-was thwarted by both the English and Scottish parliaments, James could not afford to govern either kingdom in isolation. ${ }^{2}$ More so perhaps than many of his advisors, the king

\begin{abstract}
Alison Cathcart is lecturer in history at the University of Strathclyde, Glasgow. Her current research focuses primarily on links between Scotland and Ireland within a wider archipelagic context throughout the sixteenth century. The author would like to thank Aonghas MacCoinnich, Allan Macinnes, and Roger Mason for their suggestions on earlier drafts, as well as Anna Clark and two anonymous reviewers for their constructive comments, which improved this article significantly.

${ }^{1}$ Norman Davies, The Isles: A History (London, 1999); R. R. Davies, The First English Empire: Power and Identities in the British Isles, 1093-1343 (Oxford, 2000); Robin Frame, The Political Development of the British Isles, 1100-1400 (Oxford, 1990); Brendan Bradshaw and John Morrill, The British Problem c. 1534-1707: State Formation in the Atlantic Archipelago (Basingstoke, 1996); Steven G. Ellis and Sarah Barber, eds., Conquest and Union: Fashioning a British State, 1485-1725 (London, 1995); Nicholas Canny, Making Ireland British, 1580-1650 (Oxford, 2001); Allan I. Macinnes, The British Revolution, 1629-1660 (Basingstoke, 2005); Keith Robbins, "Historians and Twentieth-Century British History, 1983-2008," unpublished paper presented at the Conference on Modern British History, University of Strathclyde, 24 June 2008.

${ }^{2}$ Letter from the Edinburgh Council to James, 3 March 1607, in The Register of the Privy Council of Scotland, A.D. 1545-1625 (RPCS), ed. John Hill Burton and David Masson, first series, 10 vols. (Edinburgh, 1877-98), 7:513. The Scots did not reject union outright but were glad that the English rejection meant they no longer had to offer lukewarm support to James's proposal.
\end{abstract}

Journal of British Studies 49 (January 2010): 4-27

(C) 2010 by The North American Conference on British Studies.

All rights reserved. 0021-9371/2010/4901-0006\$10.00 
was acutely aware of how policies implemented in one realm would have an impact elsewhere. This is evident in his government of the troublesome parts of his kingdoms, primarily the Gaelic regions of Ireland and Scotland, but also along the Anglo-Scottish border.

In his efforts to extend his royal authority throughout Britain and Ireland, James developed his policy for reforming "barbarous" subjects. This "civilizing" policy had taken shape during James's kingship of Scotland when, in the 1580s and 1590 s, the king pursued a number of initiatives aimed at bringing law and order to the western Highlands and Isles. ${ }^{3}$ While there have been some moves to analyze James's policy toward his barbarous subjects within a wider archipelagic context, this approach has not been adopted by many Scottish historians. ${ }^{4}$ Indeed, discussion of James's policy toward the Scottish Highlands and Isles after 1603 makes little reference to external influences. James's plans for civilizing the western Highlands and Isles may have begun while he was king of Scotland, but from 1603 onward James VI was king of three kingdoms, not one.

This article places James's Highland policy, and more specifically the Statutes of Iona, within a "British" or archipelagic context, which I argue is crucial to understanding the statutes in terms of Stuart policy toward its more remote regions. The Statutes of Iona of 1609 resulted from negotiations between James VI and the Highland elite and made provision for the improvement of the state of the church in the Highlands; restricted aspects of Gaelic society that were a drain on economic resources but implemented efforts to increase the general standard of living; included measures to educate the eldest sons of clan chiefs in schools in the Lowlands; and, finally, restricted military aspects of clan society. The statutes have been regarded for some time as a key part of James's scheme for civilizing his Highland subjects and extending law and order throughout the region. This is due, largely, to the work of Donald Gregory who, writing in 1836, attached "major historical significance" to "the Statutes of Icolmkill." 5

In recent decades, a number of historians have reassessed Gregory's interpretation of the statutes. From a constitutional perspective, Maurice Lee argued that

\footnotetext{
${ }^{3}$ Act of Parliament "For the quieting and keeping in obedience of the disorderit subjectis inhabitantis of the bordouris hielandis and ilis," 29 July 1587, in Acts of the Parliament of Scotland (APS), ed. T. Thomson and C. Innes, 12 vols. (Edinburgh, 1814-75), 3:461-66. This act aimed at controlling the Highlands and the Border region of southern Scotland. The Border region had been regarded as lawless for some time, and policies previously adopted there were utilized in the Highlands as well. The 1587 act also made a distinction between the west Highlands and Isles and the central and eastern Highlands. While some reference will be made to the Borders, this article will concentrate on the west Highlands and Isles. For further discussion of the central and eastern Highlands, see Alison Cathcart, Kinship and Clientage: Highland Clanship, 1451 to 1609 (Leiden, 2006). Although the civilizing policy was extended to the northern Isles, they will not form part of this study. As argued by Macinnes (British Revolution, 40, 61-62), the annexation of Orkney and Shetland was concerned primarily with James's integration of the British seas into his ius imperium.

${ }^{4}$ Jane H. Ohlmeyer, "Civilizinge of those rude parts': Colonisation within Britain and Ireland, 1580s-1640s," in The Oxford History of the British Empire, vol. 1, The Origins of Empire, ed. Nicholas Canny (Oxford, 1998), 124-47; Allan I. Macinnes, Clanship, Commerce and the House of Stuart, 1603-1788 (East Linton, 1996); Jane E. A. Dawson, The Politics of Religion in the Age of Mary Queen of Scots: The Earl of Argyll and the Struggle for Britain and Ireland (Cambridge, 2002).

${ }^{5}$ Donald Gregory, The History of the Western Highlands and Islands of Scotland, from A.D. 1493 to A.D. 1625 (Edinburgh, 1836; repr. 2008), 330-33; Martin MacGregor, "The Statutes of Iona: Text and Context," Innes Review 57, no. 2 (Autumn 2006): 111.
} 
their significance has been overstated. Julian Goodare asserted that the statutes were "incomplete, incoherent, illogical and paradoxical." Within wider British and imperial contexts, David Armitage regarded the statutes as part of the development of seventeenth-century colonial theory in Scotland, while Allan Macinnes interpreted the statutes as an attempt to integrate the Highlands into wider Scottish society. ${ }^{6}$ Martin MacGregor agreed with Macinnes's conclusions, asserting the "radicalism - or realism" of the statutes and their implications for clan society. In short, the shift toward modernism resulted when the Highland elite shifted away from their traditional function of clan chiefs and accepted new political, economic, and legal realities rather than as a response to legislation issued from the center. ${ }^{7}$ Ultimately, however, MacGregor challenged Goodare's conclusion that "the Statutes were a poor piece of policy which were consequently marginalized."

MacGregor's argument was based on a detailed analysis of the text of the statutes, highlighting the need for historians to go back to the original sources. In doing so, MacGregor pointed out what he considered to be the inconsistencies in Goodare's interpretation, arguing overall that the statutes represented an important achievement in royal policy toward the Highlands. Although MacGregor sought to focus on both "text and context," much of his argument related to text and, in comparison, the argument regarding context is limited. ${ }^{9}$ In taking MacGregor's recent article as my starting point, I do not disagree with its main conclusions. Rather in what follows I seek to elucidate a significant gap in MacGregor's work by placing the Statutes of Iona in a wider context, highlighting how an appreciation of the archipelagic situation can inform understanding of the Scottish situation.

\section{THE SITUATION IN SCOTLAND}

In order to understand the archipelagic context fully and, consequently, where the statutes sit in relation to the Plantation of Ulster, which also began in 1609 , it is important to return to the 1580s and 1590s and the formulation of James VI's civilizing policy for Scottish Gaeldom. From the moment James VI began his personal rule in Scotland in the mid-1580s, he sought to bring the Highlands and Isles to order by initiating a number of policies intended to "civilize" the inhabitants of the western Highlands and Isles. ${ }^{10}$ On occasion these efforts met with

${ }^{6}$ Maurice Lee, Government by Pen: Scotland under James VI and I (Urbana, IL, 1980), 75-82, 136-47; Julian Goodare, "The Statutes of Iona in Context," Scottish Historical Review 77, no. 203 (April 1998): 31-57; David Armitage, The Ideological Origins of the British Empire (Cambridge, 2000), 55-58; Macinnes, Clanship, 56-87.

${ }^{7}$ Macinnes, Clanship, ix; MacGregor, "Statutes of Iona," 156-57. See also David Stevenson, Highland Warrior: Alasdair MacColla and the Civil Wars (Edinburgh, 1980), 20-31; Maurice Lee, "The Government of Scotland after 1603," Scottish Historical Review 55, no. 159 (1976): 41-53, reprinted in The "Inevitable" Union, ed. Maurice Lee (East Linton, 2003), 133-44; Michael Lynch, "James VI and the "Highland Problem," in The Reign of James VI, ed. Julian Goodare and Michael Lynch (East Linton, 2000), 208-27.

${ }^{8}$ MacGregor, "Statutes of Iona," 112-13.

${ }^{9} \mathrm{Ibid}, 113$. MacGregor acknowledges the need for greater contextualization.

${ }^{10}$ Recent interpretations of James VI's Highland policy have viewed them from a state-formation perspective. In reality, James's policies, including naval expeditions to the Isles (most of which were abandoned due to cost), extracting promises of good behavior from the Highlanders known as surety and caution, royal favor for those who cooperated with the crown and forfeiture for those who con- 
success; in the late 1580s and 1590s, various Highland chiefs submitted and gave assurances for their good behavior. Unfortunately for James, these submissions were tenuous; lawlessness and blatant flouting of royal authority remained the rule rather than the exception. ${ }^{11}$ What was needed was a more systematic, far-reaching policy, subsequently to be expressed in James's civilizing of the region that aimed at "reducing . . . the rebellious inhabitants thairof to obedience . . . establishing of peace, justice and quietnes," transforming the barbarous nature of the Highlanders, stimulating commercial development, increasing crown revenue, and, thereby, integrating the region fully into Scottish society. Such policies were wrapped up in the rhetoric of religion, law, and order, designed to appeal to Lowland society where many were reluctant to support the king's expeditions to the west. ${ }^{12}$

By the late 1590s with the civilizing of the Highland Gaels under way, James was fluctuating between various policies, including plantation. In his advice to his son Henry, Basilicon Doron, published in 1598, James discussed the Highland problem and the best way to deal with the situation. Here James asserted that his plan for the Highlanders was to plant "Colonies among them of answerable Inlands subiects that within short time may reforme and ciuilize the best inclined among them; rooting out or transporting the barbarous and stubborne sort, and planting ciuilitie in their rooms." ${ }^{13}$ The introduction of a plantation policy was a reaction to ongoing lawlessness in the west Highlands and the failure of previous efforts to extend law and order throughout the region. Initial efforts to plant the west Highlands and Isles had begun earlier in 1596 when Angus MacDonald of Clan Donald South submitted in writing to the king. ${ }^{14}$ MacDonald agreed to hand over his eldest son James as a hostage, to "remove himself, his family and dependers, and all others who are not actual tenants or possessors of the ground, out

sistently rebelled, were little more than a sophisticated repeat of the policies adopted by his grandfather and great-grandfather, James V and James IV, respectively. Indeed James may well have taken note of Lindsay of Pitscottie's account of the policy of James V which "brocht the yllis . . . in goode ruell"; Robert Lindesay of Pitscottie, The History and Chronicles of Scotland. From the Slauchter of King James the First to the Ane Thousande fype hundreith thrie scoir fyftein zeir, ed., Æ. J. G. Mackay, 3 vols. (Edinburgh, 1899-1911), 1:352.

${ }^{11}$ Since, arguably, the fourteenth century, the "Highlands" had been regarded increasingly as a region lacking in law and order where the crown's authority was repeatedly ignored. What the crown, and most of Lowland society, failed to appreciate was the economic situation which produced high levels of petty tit-for-tat raiding in the region. Combined with ever-increasing competition over land this unrest confirmed the view of the Highlands as a "lawless" region. By the time James VI succeeded to the Scottish throne, these assumptions were accepted without question.

${ }^{12}$ King and Council commission against Lewis, 18 July 1605, RPCS, 7:87-88; Letter from James to the Edinburgh Council, 9 May 1608, RPCS, 8:502. James wrote from Whitehall to the council in Edinburgh acknowledging discontent on the part of some who were charged to assist the planned expedition to the Isles. The king reiterated the command that they were to assemble, arguing that the venture was "so necessarie to oure service and so beneficiall to that hole Estate."

${ }^{13}$ James VI and I, Basilicon Doron, in King James VI and I: Political Writings, ed. Johann P. Sommerville (Cambridge, 1994), 24. This reference to plantation is an indication of James's archipelagic awareness, drawing on Irish precedents to be applied within a Scottish context. Also it may have been a rather self-conscious attempt to show an English audience that he was capable of dealing effectively with the Irish situation. This was crucial in light of the backdrop of Hugh O'Neill's rebellion of the 1590 s.

${ }^{14}$ Otherwise known as the MacDonalds of Dunivaig. In 1589 they had separated from the MacDonalds of the Glens, the Irish branch of the family that became known as the MacDonnells. 
of the bounds of Kintyre and isle of Giga," and accept new crown tenants, notably in Islay and Kintyre, the traditional patrimony of his clan. Although this plan was never implemented, it was not long before the policy of plantation was extended to other parts of the region, albeit with a significant departure. ${ }^{15}$

The plans for Islay, Kintyre, and Gigha had involved the Hebridean chiefs, but future plans would involve outsiders, effectively supplanting the traditional elite. Foundations were laid through the 1597 Act of Parliament, which required all landowners to appear before the council and show titles to land they inhabited; plans for the plantation of Lewis soon followed. Torquil MacLeod, chief of the MacLeods of Lewis, was forfeited on account of his failure to produce the required documentation. The lands of Lewis, Ronalewis, the Shiant Islands, and Troutternish in Skye reverted to the crown, theoretically leaving the way clear for James to implant "civilized," that is, God-fearing, rent-paying, obedient Lowland subjects into the Highland region. ${ }^{16}$ In doing so, James hoped that the barbarous inhabitants would become imbued with Lowland values and behavior, resulting in the Highlanders becoming fully assimilated into the Scottish realm. However, there had been little anticipation of the level of opposition the planters would face from the inhabitants of Lewis, and the first attempt ended in 1601 with the planters either meeting their death at the hands of the islanders or fleeing back to the safety of Fife. ${ }^{17}$ These initial setbacks did little to alter the king's mind, or indeed the minds of the adventurers. After all, there had been a degree of opposition and resentment to all efforts by the crown to intervene in Highland affairs, but those involved believed this could be overcome. Consequently, a second attempt began in August 1604. ${ }^{18}$

By this time, James VI, no longer resident in Edinburgh, was managing the affairs of his three kingdoms from Westminster. In 1603, James had inherited not just the thrones of England and Ireland but also the law-and-order problem that

\footnotetext{
${ }^{15}$ Angus MacDonald's letter of submission to James, 8 October 1596, RPCS, 6:24-25; Offers made by MacDonald of Knockrinsay to James, 6 September 1599, RPCS, 5:321; Donald Gregory, History of the Western Highlands, 268-74. Angus had sent his son James to court to make his submission. Although James was detained as a hostage for his father, Angus did not fulfill any other of the conditions; Gregory, History of the Western Highlands, 267-79, 272-74, 280-84, 287-90.

${ }^{16}$ Act of Parliament "The inhabitantis of the iles and helandis Suld schwa thair haldingis," 16 December 1597, APS, 4:138-39; Act of Parliament "Ratificatioun of the contract of the Lewis," 29 June 1598, APS, 4:160-64; Certain councilors nominated to deal with matters concerning the Isles, 4 May $1598, R P C S, 5: 455$; Ratification of the contract concerning the island of Lewis, 29 June 1598, RPCS, 5:462-63; Gregory, History of the Western Highlands, 276-77, 279. Lewis would be the only region planted.

${ }^{17}$ This is quite remarkable considering the unrest that resulted from disputes over land possession in the Highlands. At the same time, James was well aware of the military capabilities of his Highland subjects, many of whom had considerable experience of warfare in Ireland. It suggests either a severe underestimation of opposition to this policy or utter contempt for the inhabitants of the region.

${ }^{18}$ Proclamation for musters for recovery of island of Lewis, 19 July 1602, RPCS, 6:420-22; Caution for the portioners of Lewis, 8 March 1603, RPCS, 6:545-46; Act in favor of the gentlemen of Lewis, 8 March 1603, RPCS, 6:546. As early as July 1602, James issued proclamations regarding an attempt to regain Lewis while also commenting how those involved in the first plantation were trying to shirk their responsibilities.
} 
existed in Ireland, most notably in the north. ${ }^{19}$ As king of Scotland he had been all too aware of how events in one realm could have repercussions elsewhere. Although he was now in London, the situation in Scotland warranted his attention. Aware that lawlessness in Scotland had the potential to spill over into Ireland, and vice versa, while heightening unease at the English court, James stated "that it cannot stand with his Hienes honour and princely dignitie that sic a infamous byke of lawles lymmaris salbe sufferit in ony pairt of his Majesties dominions." ${ }^{20}$ Consequently, in February 1605 the king wrote from London to the three estates in Scotland encouraging the promotion of royal policy and, turning his attention to the Isles, expressed his hope that they "may be reduceit to oure obedyence, coloneis of civile and industrious people planted thair," whereby barbarity and poverty would be stamped out, while trade and profit would increase.

Ongoing opposition to crown policy from the inhabitants of the Isles was perceived in London as evidence of the need for rigorous implementation of plantation. Consequently, on 18 July 1605 James asserted that "the interpryse of the conques of Lewis . . . sal be yit prosequuted . . . in a mair substantious maner nor it wes befoir, as alswa that the haill remanent Ilis and lands nixt adjacent quha are now disobedient sal be reducit to his Hienes obedience." ${ }^{21}$ A commission of lieutenancy in the western Isles and Kintyre was granted to David Murray, Lord Scone, on 8 August 1605 to undertake an expedition to the region for "the furtherance and advancement of His Majesteis authoritie and service," although the commission itself gave Scone very few powers. A warrant was issued for Angus MacDonald of Clan Donald South and other chiefs in the western Highlands and Isles to appear before Lord Scone in Kintyre and render their castles to crown forces, but the expedition achieved little. It was almost a year later before Scone gave an account of his visit to the west, which had resulted in the submission of only one chief, Angus MacDonald, who nonetheless promised to pay his rents for Kintyre and Islay. This refusal by Highland chiefs to submit to James's royal authority, compounded by the situation in Lewis, was "a matter twitching His Hienes in honour." Indeed, as he had declared to the three estates in Scotland the previous year, bringing the Isles to order would benefit the whole nation

\footnotetext{
${ }^{19}$ For centuries Scots had been migrating to and settling in the north of Ireland and throughout the sixteenth century remained the proverbial thorn in the side of Tudor monarchs. For the most part the English regarded the expulsion of the Scots as crucial for the settlement of the north, although at times alliance was made with the MacDonalds against the O'Neills. Meanwhile, the efforts of the English to utilize the influence of Archibald Campbell, fifth earl of Argyll, to deal with the situation were promising, but the venture did not come to fruition (Dawson, Politics of Religion, 128). Such inconsistency in policy exacerbated levels of unrest, and the English were unable to deal with the movement of Scots into the north. James VI had been content to allow his Highland subjects to cause problems for Elizabeth, but as his succession to the English crown loomed ever closer, the king realized the necessity of extending law and order throughout Ireland.

${ }^{20}$ Proclamation concerning the inhabitants of Lewis, 18 July 1605, RPCS, 7:89; Letter from the Edinburgh Council to James, 3 March 1607, RPCS, 7:513-14, n. 1. James was aware of English attitudes toward the Scots.

${ }^{21}$ King and Council commission against Lewis, 18 July 1605, RPCS, 7:84-87; Proclamation concerning the inhabitants of Lewis, 18 July 1605, RPCS, 7:89-90; Charges for rendering the castles of the Isles, 18 July 1605, RPCS, 7:87-89; Charges for rendering limfads and galleys, 18 July 1605, RPCS, 7:87-89, 87; M. Perceval-Maxwell, Scottish Migration to Ulster in the Reign of James VI(London, 1973), 12.
} 
economically, but it would also increase Scotland's reputation in a wider European context. ${ }^{22}$

James was aware of the problem of his "north," the north and west Highlands and Isles, where men followed clan chiefs and lived according to their own rules. ${ }^{23}$ Highland lawlessness had been of concern to Scottish monarchs throughout the previous centuries, and especially to James V in the 1530s; but James VI and I, as monarch of three kingdoms, was particularly preoccupied with it because of the detrimental impact it could have on his attempts to pacify the north of Ireland. ${ }^{24}$ In July 1604 the king confirmed an earlier grant of all the lands of the Route and the Glens in the north of Ireland to Sir Randal MacDonnell. ${ }^{25}$ This grant contained a clause that authorized Sir Randal to divide the territory into parts of around 2,000 acres and build a castle or mansion house in each. Later, between December 1604 and February 1606, James issued instructions and grants that laid the foundations for the Hamilton-Montgomery plantation of Down and the Ards in the northeast of Ireland. ${ }^{26}$ If such endeavors were to be successful, James would have to limit the movement of the Highlanders from the west of Scotland to the north of Ireland. ${ }^{27}$ In short, as far as James was concerned, the situation in the Highlands was of "grite hurt" to "the commonweill." It was offensive also to his position as sovereign. ${ }^{28}$

While James liked to theorize about kingship, as The Trew Law of Free Monarchies highlights, in practice he was prepared to compromise to reach a workable solution, as suggested in Basilicon Doron and evident in his grant to the Irish Catholic Randal MacDonnell. ${ }^{29}$ The fundamental principle that James would not compro-

\footnotetext{
${ }^{22}$ Proclamation for the Isles, 13 June 1605, RPCS, 7:59-60; Proclamation for the west Isles, 27 June 1605, RPCS, 7:68-69; Warrant for pressing of mariners, 27 June 1605, RPCS, 7:69-70; Commission of lieutenancy in the west Isles and Kintyre, 8 August 1605, RPCS, 7:115-17; The Gentlemen Adventurers of Lewis, 31 July 1606, RPCS, 7:229; Letter from James to the Three Estates of Scotland, 11 February 1605, RPCS, 7:466. James knew that success in this venture would reflect on his standing, both at home and on the continent. Perhaps specifically he had the Dutch in mind, as their fishing in the region was hampered by the lawless activities of his island subjects. See Aonghas MacCoinnich, "Native, Stranger and the Fishing of the Isles, 1611-1637," paper in Occasional Proceedings of Northern European Historical Research Network, delivered at Aberdeen, August 2005.

${ }^{23}$ Robert Bartlett, Gerald of Wales (Oxford, 1982), 158-77; David B. Quinn, "Ireland and Sixteenth Century European Expansion" in Historical Studies I, ed. T. Desmond Williams (London, 1958), 20-32; Debora Shuger, "Irishmen, Aristocrats, and Other White Barbarians," Renaissance Quarterly 50, no. 1 (Spring 1997): 494-525. James's civilizing policy had its roots in classical antiquity. Shuger points out that "civility," as a program of reform, was not limited to the Gaels of Ireland and Scotland.

${ }^{24}$ Allan I. Macinnes, "Crown, Clan and Fine: The 'Civilizing' of Scottish Gaeldom, 1587-1638," in Northern Scotland 13 (1993): 31.

${ }^{25}$ Grant to Sir Randal MacDonnell of the Route and the Glens in Antrim and Rathlin Island, 14 April 1604, BL Add. MS, 36775, fols. 138b-139; Confirmation of earlier grant to Sir Randal MacDonnell, 6 July 1604, Public Record Office of Northern Ireland (PRONI), D2977/5/1/1/2.

${ }^{26}$ Perceval-Maxwell, Scottish Migration to Ulster, 47-56; Letter from James to Sir Arthur Chichester, 16 April 1605, Calendar of State Papers relating to Ireland (CSPI), ed. Hans Claude Hamilton et al., 24 vols. (London, 1860-1911), 12:271-72.

${ }^{27}$ There was a long tradition of Scottish fighting men migrating to Ireland, either on a temporary or permanent basis. See Gerald A. Hayes-McCoy, Scots Mercenary Forces in Ireland, 1565-1603 (Dublin, 1937); Dawson, Politics of Religion, 5-6, 51-52, 163-64, 202-5.

${ }^{28}$ Proclamation concerning the inhabitants of Lewis, 18 July 1605, RPCS, 7:89-90.

${ }^{29}$ Sommerville, King James VI and I, 1-61, 62-84; Jenny Wormald, Court, Kirk and Community: Scotland, 1470-1625 (Edinburgh, 1981), 148.
} 
mise on, however, was recognition of his royal authority. ${ }^{30}$ While the Highland elite undoubtedly recognized James as their king, holding their lands from the crown by charter, their compliance with crown policy was marginal. Local issues came to the fore too readily, and, due to complex networks of alliances between clan chiefs, a minor dispute could escalate rapidly, leading to widespread disorder. James saw this problem as stemming from the ongoing refusal on the part of Highland chiefs to acknowledge his sovereignty and remained even more determined to deal with continued lawlessness in the west. James sought to utilize a tried and tested, and relatively successful, initiative of his predecessors and turned to local and regional magnates to help execute royal policy in the west.

Throughout the sixteenth century, successive Scottish monarchs had delegated responsibility for the Highlands and Isles to the Gordons of Huntly in the North Isles and the Campbells of Argyll in the South Isles. James now looked to the heads of these houses. On 3 December 1606 James declared his intention that George Gordon, sixth earl and first marquess of Huntly, should "reduce the North Yllis . . . to civilitie and oure obedyence." The finer details of the plan were thrashed out over the following months, and on 30 April 1607 Huntly agreed to undertake the business of settling the region, to be achieved by extirpation of the inhabitants, specifically the Clan Donald. Fortunately for them, the Clan Donald and the rest of the inhabitants of the North Isles received an eleventh-hour reprieve, albeit indirectly. While Huntly offered to undertake the project at his own expense, there had been no agreement concerning the annual duty to be paid by the marquess. Huntly would not agree to more than $£ 400$ Scots per year, which the Privy Council considered "a very meane dewytie for the haill North Yllis." ${ }^{31}$ At the same time, James finally gave in to pressure from an increasingly outspoken Protestant kirk that sought to push ecclesiastical proceedings against Huntly on

\footnotetext{
${ }^{30}$ Roger Mason, "Renaissance and Reformation: The Sixteenth Century," in Scotland: A History, ed. Jenny Wormald (Oxford, 2005), 138-39. I would like to thank Alan Macdonald, University of Dundee, for discussing this point with me.

${ }^{31}$ Articles proposed by the council concerning the marquis of Huntly's undertaking for the North Isles, 30 April 1607, RPCS, 7:360-62; Letter from James to the Edinburgh Council concerning the marquis of Huntly, 3 December 1606, RPCS, 7:504; Letter from James to the Edinburgh Council concerning the marquis of Huntly, 16 March 1607, RPCS, 7:516-17; Letter from the Edinburgh Council to James concerning the marquis of Huntly, 26 March 1607, RPCS, 7:518-19; Letter from James to the Edinburgh Council concerning the marquis of Huntly, 7 April 1607, RPCS, 7:520-21; Letter from the Edinburgh Council to James concerning the marquis of Huntly, (?) May 1607, RPCS, 7:523-24; Letter from James to the Edinburgh Council concerning the marquis of Huntly, 20 May 1607, RPCS, 7:524-25; Letter from the Edinburgh Council to James concerning the marquis of Huntly, 19 June 1607, RPCS, 7:528-29; Goodare, "Statutes of Iona," 33. Huntly agreed before the council "to tak in hand the service of setling of the North Yllis undir his Majesteis obedyence . . . and to putt ane end to that service be extirpatioun of the barbarous people of the Yllis within a yeare." Although he had been extending his authority in this region throughout the later sixteenth century, Huntly's refusal to agree to a higher annual duty may have been a deliberate move on his part to stall, if not thwart completely, this plan. The marquess, aware of the failure of the first two attempts at plantation of Lewis by the Fife Adventurers and of the third attempt under way but reaching no successful conclusion, would have had little desire to see such an eventuality played out in the North Isles under his watch.
} 
account of his Catholicism. ${ }^{32}$ In June 1607, Huntly was ordered to confine himself within the burgh of Aberdeen, thereby ensuring that he played no further part in the plantation in the Isles. ${ }^{33}$

The fortunes of Archibald Campbell, seventh earl of Argyll, in the Isles were rather different. The Campbell clan had been acquiring further territory and influence stealthily in the southwest Highlands and Isles of Scotland ever since the forfeiture of the MacDonald lordship of the Isles in 1493. The situation was further exacerbated by the fact that successive earls of Argyll had been able to gain crown commission to pursue unruly Highland clans, specifically the Clan Donald, and had benefited from such service to the crown. But the Campbells had faced internal weakness during the minority of the seventh earl, and James appeared reluctant to extend Campbell jurisdiction in the west. ${ }^{34}$ However, in the early years of the seventeenth century, Argyll had been instrumental in executing James's action against the MacGregors, and in return the king "maid promise to give to the Erle of Ergyle ane worthie reward, to remayne heretablie with him and his aires heirafter." The reward asked for in 1607 was a "gift of the landis of Kintyre," lands previously held by the Clan Donald South. In putting forward Argyll's case, the Privy Council reminded James that the lands were small and that "na proffeitt thay evir importeit to the King, his Majestie often tymes being driven to put the cuntrey to greitar chairges in the space of thrie or four yeir for getting in of the rent thairof, quhilk is nocht greit, than mycht haif doubled the pryce and utter valew of the haill land." The council continued, asserting that a grant of Kintyre to the earl would assist Argyll in action against the Clan Donald, "the strangest piller of all the broken hieland men, quha nevir in any aige wer civill, bot hes bein the scoolemaisteris and fosteraris of all barbaritie, savaignes, and crueltye - hes evir from the beginning bein addictit nocht only to rebellioun within this continent land and the iles, bot evir wer assisteris of the northern Irische people, dwelling in Ireland, in all thair rebellionis." Thus, Argyll's action against the Clan Donald "nocht only will . . . procuire thair ruitteing out and utter suppressing, bot upoun that same respect will evir be ane feir to those in the northe of Ireland to rebel, having ane enemye lyand sa neir to thame." The council was well aware of the wider context of James's policy and emphasized that the gift of Kintyre to Argyll would assist in establishing law and order in Scotland-and Ireland. This reflects the view long held by successive English governments that the west of Scotland constantly encouraged rebels in the nearby north of Ireland and supplied them with men and munitions. Pacifying the west of Scotland, therefore, would ensure

\footnotetext{
${ }^{32}$ James had managed the conflicting interests of the Catholic party and the kirk in Scotland successfully by making concessions to one in order to gain support for measures against the other. By 1607 he had neutralized the threat of the radical Presbyterians in Scotland but was pushing through reform of the church along Erastian lines. The action against Huntly was to satisfy an already disgruntled kirk, as well as wider Protestant opinion throughout his kingdoms in the wake of the failed gunpowder plot. Gordon Donaldson, Scotland: James V-James VII (Edinburgh, 1965), 186-96, 204-8; Mason, "Renaissance and Reformation," 136-42; Jenny Wormald, "Confidence and Perplexity: The Seventeenth Century," in Wormald, Scotland, 145-53.

${ }^{33}$ Council order for the arrest of vessels to be employed in reducing the Isles, 21 May 1608, RPCS, 8:94

${ }^{34}$ After Huntly's defeat of crown forces, led by Argyll, at the battle of Glenlivet in 1594, Argyll was committed to ward for a short period. However, Campbell influence in the west of Scotland was such that, at times, James would come to rely on him for execution of crown policy in the region.
} 
stability in the north of Ireland. Also, in economic terms it would be of great benefit, a point the council, in advocating "the removeing of that mischevous Clan . . . thair utter extirpatioun and ruitteing out," made clear to the king: "sa lang as the said Clan Donald remaynes unremoveit furth of the saidis landis, his Majestie nor na utheris sal half any proffeit, and the uncivilitie and barbaritie sall continew nocht only thair bot in the Iles." James needed little more persuasion, and Argyll was granted legal tenure of the lands of Kintyre on 30 May $1607 .{ }^{35}$

The acquisition by the Campbell chief of land formerly pertaining to Clan Donald South was not well received in the west, and it resulted in the spontaneous outbreak of rebellion. On 16 July 1607, Sir Arthur Chichester, lord deputy of Ireland, wrote to the English Privy Council with intelligence that Angus MacDonald and his men were planning an attack on Kintyre, also stating he had written to the earl of Argyll. ${ }^{36}$ Two weeks later, on 31 July 1607, the Scottish Privy Council likewise noted that Angus MacDonald and others of the Clan Donald had amassed a force of men and galleys with the intention "to invaid and persew his Majesteis guid subjectis be sey and land." As a result of this unrest by the Highlanders, on 12 August 1607 the earl of Argyll received a commission of lieutenancy and justiciary that extended across much of the South Isles. ${ }^{37}$

In presenting Argyll's case to the king, the council had mentioned the earl's action against the Clan Donald South as important not just within a Scottish context, but within a wider archipelagic one. This was a calculated move. The council was aware of the king's belief that unrest in one of his kingdoms had repercussions in another, and James had emphasized the importance of his policies toward the Highlands as being not just for the commonweal of Scotland, but for his "haill impyre." The council asserted that Argyll would bring stability to the Highlands and secure the coastal borders against the Irish rebels, who sought aid from and refuge in the west of Scotland. This was a deliberate attempt to ensure James would grant Kintyre to Argyll, rather than continue to work toward a solution involving the MacDonald chief himself and his son James. ${ }^{38}$

Earlier in the 1590s Argyll had been threatened by the king's attempts to reach a settlement with the Hebridean elite. Agreements regarding plantation in the

${ }^{35}$ Letter concerning the earl of Argyll's claim to Kintyre, (?) 1607, RPCS, 7:749-50; Grant of lands in Kintyre to the earl of Argyll, 30 May 1607, in Registrum Magni Sigilli Regum Scotorum (RMS), ed. John Maitland Thomson et al., 11 vols. (Edinburgh, 1912-), 6:1911; Letter from Sir George Carey Lord Justice of Ireland to Sir Robert Cecil, 3 December 1599, CSPI, 8:295-96; "Remedies [for Irish incursions], and the Benefits which will accrue from them," n.d., CSPI, 11:666-67; "Ratification to the Erle of Argyill," 28 June 1617, APS, 4:559-60. Since the 1580s James had spoken repeatedly of the rich economic resources of the Highlands and Isles that were underexploited by the inhabitants while, at the same time, aware that the crown had never received full rental from the region.

${ }^{36}$ Letter from Sir Arthur Chichester to the London Council, 16 July 1607, CSPI, 13:223. Chichester had "received intelligence from the sea-coasts of Ulster, and especially of Antrim, that Angus M'Connell . . . with some other confederates . . . were up in arms in the Islands of Scotland, intending to make attempts upon those coasts, and especially that of Cantyre (of which Angus pretends to be lord) and also upon the opposite parts of this realm."

${ }^{37}$ Proclamation concerning MacDonald of Dunivaig, 31 July 1607, RPCS, 4:423; Commission of justiciary to the earl of Argyll over the Isles, 12 August 1607, RPCS, 7:426-72. The commission excluded the North Isles.

${ }^{38}$ After Angus MacDonald's submission in the wake of Lord Scone's expedition, the chief had attempted to negotiate with council and had submitted proposals; see Robert Pitcairn, ed., Criminal Trials in Scotland, 3 vols. (Edinburgh, 1833), 3:365-66. 
western Isles were made with Angus MacDonald of Clan Donald South in 1596 and with Angus's son, James MacDonald of Knockrinsay, in 1599, although these were never implemented. ${ }^{39}$ In 1597 James MacDonnell of the Glens in Ireland had won the favor of James VI while visiting the Scottish court, and, although he was denied title to Kintyre and Islay, he was knighted in December, becoming Sir James MacDonnell of Dunluce and gaining lands in south Kintyre. ${ }^{40} \mathrm{Mac}-$ Donnell sought to reunite the Clan Donald lands, but Argyll, fearful of a reunited and reinvigorated MacDonald lordship that straddled the Irish Sea, was able to thwart such endeavors through the influence he had at council. ${ }^{41}$ As a consequence of the failure to reach a workable solution with the Highland chiefs, combined with ongoing rebellion on Lewis, the king looked to regional magnates and Lowland lords for assistance in civilizing the region. Argyll was ready to exploit any opportunity to extend his authority in the Isles, and while the MacDonalds continued to feud among themselves, the Campbells worked to extend their influence at Clan Donald expense. ${ }^{42}$ However, events in Ireland in 1607 and 1608 would alter the course of Highland history dramatically.

\section{THE SITUATION IN IRELAND}

Although James had been developing plantation schemes in relation to the western Isles of Scotland, on inheriting the throne of Ireland in 1603 he was reluctant initially to extend this policy into Ireland. Michael Perceval-Maxwell argued that the main reason for his change of mind was financial. When James realized the cost of maintaining order in Ulster, the idea of plantation suddenly became more attractive, although it is questionable whether at this juncture James envisaged extending such a plan across all of Ulster. Indeed, Perceval-Maxwell held that pre1607 plantation meant simply "the changing of Irish tenure to English, with the introduction of non-Irish persons being kept to a minimum." ${ }^{\prime 3}$ In 1605, when James had granted the lands formerly held by Con O'Neill of Clandeboye in Down and the Ards to a Scot, James Hamilton, the son of a minister from Dunlop in Ayrshire, part of the grant stipulated that one-third of these lands would be passed to Hugh Montgomery, sixth laird of Braidstane, and another third to Con O'Neill himself. Nonetheless, Hamilton and Montgomery were to provide enough Scottish

\footnotetext{
${ }^{39}$ Gregory, History of the Western Highlands, 288-90; and see n. 15 above.

${ }^{40}$ Grant to James MacDonald of Dunluce of lands in Kintyre, 4 May 1597, RMS, 6:554. It is not clear exactly how James MacDonnell won the favor of the king. Gregory (History of the Western Highlands, 266-69, 273-74) asserts that James requested the assistance "as should be required" of MacDonnell in an expedition of 1596 to the Isles. The following year, MacDonnell "accepted an invitation to visit the Court of Scotland" when he was "described by several Scottish writers of the period as a man of handsome appearance and dignified manners; and, although ignorant of the Lowland tongue, he speedily became a great favorite"; The Warrender Papers, vol. 2., ed. Annie I. Cameron (Edinburgh, Scottish History Society, 1932), 429-30.

${ }^{41}$ Pitcairn, Criminal Trials in Scotland, 3:365-66; Gregory, History of the Western Highlands, 310-11.

${ }^{42}$ Argyll had been able to manipulate the council in order to thwart the efforts of Angus MacDonald of Dunivaig and his son, Sir James, to secure continued possession of Kintyre and Islay. See Gregory, History of the Western Highlands, 272-74, 287-90, 305-13; Pitcairn, Criminal Trials in Scotland, 3: 365-66.

${ }^{43}$ Perceval-Maxwell, Scottish Migration to Ulster, 74, 76.
} 
and English tenants to secure plantation of one-third of O'Neill's estate. Of greater significance, however, is the fact that Down and Ards were divided up in such a way as to ensure that the Scots Hamilton and Montgomery had control of the east coast. ${ }^{44}$ This was a strategic move: it offered a base from which expeditions could be launched, while it also ensured the continuation of trade. ${ }^{45}$

James's agenda for Ulster at this stage may not have included widespread plantation, but the king was warming to the strategic and economic benefits he might reap from such a policy. Scots had been settling in the north of Ireland unofficially for decades, and even in 1606 Sir Thomas Craig commented independently on the "stream of emigrants" that passed daily into Ulster. ${ }^{46}$ James now envisaged the planting of significant numbers of loyal, law-abiding "British" subjects who would advance commercial activities in the area, and in some cases there was no need to remove the tenants as they could be used to work the land.

Removal of the Irish elite had not been part of his original plan. Indeed, immediately after his succession to the thrones of England and Ireland, O'Neill submitted to the king, receiving in return a pardon and a patent to his lands. Rory O'Donnell likewise submitted and soon after was elevated to an earldom. A short time later, James issued a grant of the Route and the Glens to Sir Randal MacDonnell. This was more than recognition of the de facto situation in the north; it was an indication of James's willingness to work with those who were prepared to cooperate with him. James's preference may well have been for Protestant undertakers whose loyalty he could be assured of, and, as he later asserted, "the settling of religion, the introducing civility, order, and government amongst a barbarous and unsubdued people" were "acts of piety and glory, and worthy always of a Christian prince to endeavour." ${ }^{27}$ In practice, however, James was happy to accept Catholic, and indeed Irish Catholic, undertakers like Randal MacDonnell of Antrim, brother of Sir James MacDonnell of Dunluce, so long as they acknowledged James's authority and his position as king of Ireland. ${ }^{48}$ While the Scottish branch of the family continued to cause trouble, the Irish branch appeared much more amenable to cooperation with the crown.

James sought to work with Irish lords like MacDonnell in order to pacify the north of Ireland, and he aimed for further cooperation with O'Neill and O'Donnell too, as he considered this to be the best and cheapest means of stabilizing the region. Forced removal of the native elite had not been given serious consideration, although he had initiated such a policy in the Highlands and Isles of Scotland, albeit without much success. It was the decision by the Irish lords themselves to depart for the continent-the Flight of the Earls-that offered James the opportunity to develop a scheme for plantation in Ulster that was much more ambitious than anything he had conceived of previously.

\footnotetext{
${ }^{44}$ Grant to Hugh Montgomery and James Hamilton, 5 November 1605, PRONI, D4216/B/1-2.

${ }^{45}$ Perceval-Maxwell, Scottish Migration to Ulster, 49-60.

${ }^{46}$ Sir Thomas Craig, De Unione Regnorum Britannic Tractatus, ed. C. Sanford Terry (Edinburgh, Scottish History Society, 1909), 446-47.

${ }^{47}$ Submission of the earl of Tyrone, 8 April 1603, CSPI, 11:13-14; Letter from James to the earl of Devonshire, Lieutenant of Ireland, 4 September 1603, CSPI, 11:79-80; Letter from James to Sir Arthur Chichester, 21 December 1612, CSPI, 15:310.

${ }^{48}$ James's personal attitude toward Catholicism was clear. His wife, Anne of Denmark, his chancellor, the earl of Dunfermline, and his close friend, Huntly, were all Catholics.
} 
On 18 September 1607, the Privy Council in Edinburgh noted that "some noblemen of the cuntrey of Ireland, with a nowmer of thair speciall freindis and dependairis, hes of lait, without the previtie, knawlege, and consent of his Majestie, or of the Lord Deputie of Ireland, tane schipping in Lochfuillie [Lough Swilly] for some treasonable deseygne and practize aganis his Majesties estate and cuntrey." In response, the council ordered the sheriff of Wigtown, the steward of Kirkcudbright, and the magistrates of the burgh of Kirkcudbright and all other towns along the west coast to give "diligent attendance . . . be day and nycht, upoun thair coistis and harboreyis, to espy gif ony Ireland men sall cum willinglie in thair boundis or be contrarious windis salbe drevin upoun thair coistis." If any Irishmen did land in Scotland, men and ships were to be arrested and handed over to the authorities. Concerned that the fallout from the flight would heighten an already unstable situation in the west of Scotland, this legislation was designed to try to contain the situation. But apart from this, the event passed with Scotland, or at least the Scottish administration, barely raising a collective eyebrow. ${ }^{49}$

The flight of O'Neill and O'Donnell and their associates in September 1607 certainly was unexpected, for James had harbored hopes that he might forge a workable relationship with O'Neill..$^{50}$ Their departure, and feared imminent return, focused the minds of many in Ireland and England. The Flight of the Earls, and the subsequent rebellion of Sir Cahir O'Doherty, was "providential" for James. The removal of the elite from Tyrone and Tyrconnell allowed James to take back into crown hands a large swath of land in the west of Ulster, and it offered him the opportunity to reconsider his plans for Ireland. ${ }^{51}$ Within thirteen days of the departure of the earls from Ireland, Chichester had drawn up two proposals for reallocation of their Irish estates. He promoted plans for plantation and sought to convince James that it was a sound economic move, while also securing law and order in a region with a long history of disorder. But while the Flight of the

\footnotetext{
${ }^{49}$ Council charge for arresting some men from Ireland, 18 September 1607, RPCS, 7:439. The Scottish Council's reaction, and indeed the lack of it, to the Flight of the Earls is surprising. My thanks to Nicholas Canny for helpful comments on this point.

${ }^{50} \mathrm{O}$ 'Neill's rebellion against English authority effectively ended with defeat at the Battle of Kinsale on 24 December 1601, although generous terms for O'Neill were gained through the Treaty of Mellifont of 30 March 1603. O'Neill and O'Donnell subsequently accompanied Lord Deputy Mountjoy to London to meet James who upheld the terms of the treaty, although it was widely unpopular in England. In the following years O'Neill increasingly found himself under attack from various directions including legal questions regarding his and O'Donnell's claims to land, while O'Donnell and Cuconnaught Maguire faced severe financial difficulties as well. Combined with O'Neill's growing paranoia regarding his own safety, this resulted in the three men fleeing with their families to Spain. Nicholas Canny, "The Flight of the Earls, 1607," Irish Historical Studies 17, no. 67 (March 1971): 380-99; Hiram Morgan, Tyrone's Rebellion: The Outbreak of the Nine Years War in Tudor Ireland (Woodbridge, 1993); Nicholas Canny, Making Ireland British, 174-87; John McCavitt, "The Flight of the Earls," Irish Historical Studies 29, no. 113 (May 1994): 159-73; Michael D. Finnegan, "Tyrone's Rebellion: Hugh O'Neill and the Outbreak of the Nine Years War in Ulster" (MA thesis, National University of Ireland, Galway, 2001); John McCavitt, The Flight of the Earls (Dublin, 2002); Nicholas Canny, "Hugh O'Neill [Aodh Ó Néill], second earl of Tyrone (c. 1550-1616)," Oxford Dictionary of National Biography (ODNB) (London, 2004), http://www.oxforddnb.com.

${ }^{51}$ Canny, Making Ireland British, 133-34. Elizabethan plantation schemes were justified by reference to the theory of res nullia or "empty land." In 1608 the crown claimed to have at its disposal all, or significantly large parts, of the counties of Armagh, Cavan, Coleraine, Donegal, Fermanagh, and Tyrone. County Coleraine was later designated County Londonderry. And see n. 70 below.
} 
Earls in 1607 would alter the situation in Ireland, the event had repercussions across the water in Scotland as well.

\section{THE ARCHIPELAGIC CONTEXT}

Plantation was to be advanced by Scottish and English undertakers. ${ }^{52}$ Chichester actually advocated Scottish and Irish involvement in the project from the outset, albeit in a secondary role with the English as the main undertakers. The Scots and Irish would be predominately tenants, while the English undertakers were to have the first choice of land. This attitude stemmed from his belief that a successful outcome of the scheme for the plantation of Ulster would result from integration of Irish, Scots, and English. Chichester, after all, was well aware of the extent of Scottish settlement that had already taken place in Ulster and of the success of the Hamilton-Montgomery plantation in Down and the Ards. If plantation was to succeed, the cooperation of these Scots with the crown's plans would be advantageous. ${ }^{53}$ But as plans evolved, Chichester increasingly became concerned at the role the Scots were to play in the plantation of Ulster. He was uneasy that they would be not only tenants but undertakers as well and was reluctant to see large-scale removal of the Irish if they were only to be replaced by a certain type of Scot. He explained his position in a letter to Salisbury: "if the nobility and subjects of Scotland . . . be permitted to bring over the islanders or their neighbours of those northern parts . . . more trouble and less profit will arise from thence, than if the Irish themselves held it as they now do." ${ }^{54}$

Nonetheless, Chichester continued to believe that Scottish participation in the Ulster venture was crucial for establishing and maintaining both an English presence and Protestantism. Others in the English Council advocated the removal of the Irish on account of their being "men full of poison." In 1607 the Irish attorney general, Sir John Davies, asserted that "his Majesty's blessed genius will banish all those generations of vipers out of it, and make it . . . a right fortunate island." In contrast, Chichester had pragmatic reasons for advocating accommodation with the native Irish: this would limit the extent of opposition the planters would face. ${ }^{55}$

In Scotland, however, it was the outbreak of Sir Cahir O'Doherty's rebellion in Derry in April 1608 that caused greater consternation, provoking a spate of communication between the Scottish Council and Chichester regarding the deployment of both land and naval forces in Ulster and in the Isles, as well as additional legislation that aimed to prevent movement of rebels between Scotland

\footnotetext{
${ }^{52}$ Canny, Making Ireland British, 200-201. A distinction was made between undertakers and servitors. Undertakers "would 'undertake' . . . to build defensible buildings on their property, to remove the existing occupiers . . . and to populate their lands exclusively with English or Scottish Protestant tenants." Servitors were those who had served the crown in either a civil or military capacity, and, in the Ulster context, most were expected to be former army officers. They "were also obliged to build defensible buildings on their properties, and were encouraged, but not obliged, to place English and Scottish tenants on their estates." Any native Irish who gained land were "to promote "tillage and husbandry after the manner of the English Pale."

${ }^{53}$ Canny, Making Ireland British, 192-93.

${ }^{54}$ Perceval-Maxwell, Scottish Migration to Ulster, 81.

${ }^{55}$ Letter from Sir John Davies to Salisbury, 12 September 1607, CSPI, 13:273; Canny, Making Ireland British, 191-92, 236.
} 
and Ireland. ${ }^{56}$ The rebellion of Sir Cahir O'Doherty witnessed a combined naval and land force of English, Irish, and Scots in a coordinated effort to prevent the rebels receiving aid from, or shelter in, Scotland. ${ }^{57}$ Following the outbreak of rebellion, Chichester wrote to the Scottish Privy Council on 24 April 1608. ${ }^{58} \mathrm{He}$ expressed his concern that the Highlanders and Islesmen of Scotland "being now in ill grace withe his Majestie, sould transporte over ony assistance unto thame [the Irish rebels] quhairthrough thay may grow togidder to greatair insolenceis, and bring mony otheris into thair pairtye whilkis otherwise durst not declair thameselffis." To assist his efforts, Chichester asked for two ships. They were "to be rigged and sett furth with all dew expeditioun, for refraining the comeing hither of those Ylandaris to succour the Kingis rebellis on this syde during oure prosequutioun of thame." ${ }^{59}$ Considering that the activity of Scots in the north of Ireland had been regarded for some time as an obstacle to both the successful implementation of Tudor policy and the peace and stability of the region, Chichester's fears were entirely justified.

The council in Edinburgh was also concerned. From its perspective, the rebellion had the potential to "progres ouer mony other pairtis of his Majesteis dominionis, and sua disturb the haill body of the estate." Because the rebellion in Ireland occurred "so neir to the coistis of this kingdome," the imminent arrival of "rebellious and traterous subjectis of Yrland" who continued to "prosequutis thair shamefull rebellioun and defectioun with thair haill poueris and endevoiris" carried "no litle appeirance of prejudice to this Estate, besydis the generall disturbance of his Majesteis haill impyre." Of more immediate concern was the extent to which the rebellion could undermine the ongoing preparations for the expedition to the Highlands and Isles, which sought to extend "civile societie" in the region. Indeed, the day after receiving Chichester's letter, the Scottish Privy Council ordered wapinshaws to be held on 9 May in an effort to prepare the realm against "foreyne invasioun ... domestique and intestine seditioun." ${ }^{60}$ This was followed up six

\footnotetext{
${ }^{56}$ Sir Cahir O'Doherty had been an English ally prior to this rebellion, which, far from being an attempt to overthrow the English garrison at Derry, was motivated primarily by local and personal factors. The governor of Derry, Sir George Paulet, "played a major role in provoking" the revolt that resulted from a dispute concerning the possession of Inch Island. O'Doherty's rebellion was viewed as part of the wider plot O'Neill was believed to be organizing against the crown. John McCavitt, Sir Arthur Chichester Lord Deputy of Ireland, 1605-1616 (Belfast, 1998), 140-48; Robert J. Hunter, "The End of O'Donnell Power," in Donegal: History and Society; Interdisciplinary Essays on the History of an Irish County, ed. William Nolan, Liam Ronayne, and Mariead Dunlevy (Dublin, 1995), 250-51.

${ }^{57}$ Convention of Estates concerning forces for service in the Isles, 20 May 1608, RPCS, 8:93; Commission of lieutenancy over the Isles to Lord Ochiltree, 21 June 1608, RPCS, 8:113-14.

${ }^{58}$ On the same day, Dunfermline and Sir Thomas Hamilton wrote to James VI informing him of "the treusonabill insurrection of Odochartie, and burneing of Derry in Ireland" acknowledging "the first pairt of oure dewtie wes to mak your maiestir aduerteised with the greatest speid that could be." See State Papers and Miscellaneous Correspondence of Thomas, Earl of Melros, ed. James Maidment, 2 vols. (Edinburgh, 1837), 1:44-45.

${ }^{59}$ Letter from the Lord Deputy and Irish Council to the Edinburgh Council, 24 April 1608, RPCS, 8:497-98; Letter from Sir Arthur Chichester to the London Council, 4 May 1608, CSPI, 13:501.

${ }^{60}$ Proclamation of a general wapinschaw, 25 April 1608, RPCS, 8:78; Proclamation to western shires for service against Irish rebels, 25 April 1608, RPCS, 8:78-79; Commission of lieutenancy over the Isles to Lord Ochiltree, 21 June 1608, RPCS, 8:113-14; Letter from the Edinburgh Council to certain noblemen in the west, 28 April 1608, RPCS, 8:498-99. A wapinshawing was a military muster of men within a particular region or lordship.
} 
days later with a royal proclamation stating that no one in Scotland was to provide refuge for, or give assistance to, any Irish rebels, while any that did arrive in Scotland were to be apprehended and handed over to the authorities. ${ }^{61}$

James was apprehensive too. On 9 May he wrote to his council in Edinburgh informing its members that "oure kingdome" was to be left with enough soldiers to carry out the pacification of the Isles and, if need be, assist in quashing the rebellion in Ireland. Therefore, "all leveing of souldiouris to serve in ony foreyne pairtis be expreslie inhibite and dischargeit." On the same day, Sir Thomas Phillips, an English servitor who had obtained Coleraine in 1605, wrote to the council reiterating Chichester's request for two ships but elaborating on what was required: "one of thame of goode burdyne with ordinance in hir, allowing hir ane hundreth goode men besyde sayllaris, to do some service in the revair of Lochfoyle, and other to ly in Lochsulley, to stoppe the recourse of barkis and boittis thair." 62 James was aware of the problems his council in Edinburgh was facing regarding the supply of ships, as proclamations had been made in the east for the arrest of ships to be put into service in the Isles. But he was concerned with events in Ireland as well as Scotland and directed the Scottish Council to send 200 men to Ireland under two captains and to provide two months' pay. ${ }^{63}$ On 21 June the council wrote to the governor of Carrickfergus Castle to inform him the soldiers had been sent, under captains Patrick Crawford and William Stewart. ${ }^{64}$

A few weeks later, on 13 July the council in Edinburgh wrote to Chichester. The council acknowledged that James, "in his princelie and tender affectioun whiche he indifferentlie beiris to the subjectis of boithe kingdomes, hes gevin directioun that two hundreth sojouris salbe sent frome thense to the furtherance of this service." However the council requested that "no unnecessair burdyne" be placed on the soldiers and that Chichester be "verie spairing of thair travellis unles a present and urgent necessitie so requiris." Rather, they should be kept "in reddynes attending in some commodious parte upoun the coist most ewest to our Yllis, quhair thay may be transportit and send over as the occasioun sall present." In contrast to this preoccupation regarding the Scottish soldiers sent to Ireland, the rest of the letter is full of rhetoric regarding close cooperation between the two kingdoms. While making reference to their "deir Soverane" and his "grite wisdome and providence," the Scottish Council asserts that it, and the Irish Council, "who ar memberis of one body under so gratious a soverayne and head . . . aucht to be sensible of otheris harmes" and, therefore, should keep in regular communication. If this was maintained, the two administrations could "hand in

\footnotetext{
${ }^{61}$ Royal proclamation against supplying the rebels in Ireland, 30 April 1608, RPCS, 8:82-83.

${ }^{62}$ Letter from James to the Edinburgh Council, 9 May 1608, RPCS, 8:503; Letter from Thomas Philips to the Edinburgh Council, 9 May 1608, RPCS, 8:504-5. Phillips had obtained Coleraine from James Hamilton of the Hamilton-Montgomery plantation. Hamilton had acquired large amounts of land in Ulster but was persuaded by Chichester to sell a significant amount to other English and Scotsmen. See Perceval-Maxwell, Scottish Migration to Ulster, 51-55.

${ }^{63}$ Letter from the Edinburgh Council to James, 21 May 1608, RPCS, 8:506-7; Letter from the Edinburgh Council to the governor of Carrickfergus, 30 May 1608, RPCS, 8:508; Letter from the London Council to Sir Arthur Chichester, 2 June 1608, CSPI, 13:548. On 2 June 1608, however, the council in England wrote to Chichester informing him that " 300 are to be sent over from Scotland."

${ }^{64}$ Letter from the Edinburgh Council to the governor of Carrickfergus, 21 June 1608, RPCS, 8: 511.
} 
hand, harte in harte, and foote for foote" cooperate to the honor of the king and for the pacifying of both their respective regions. ${ }^{65}$

Despite the rhetoric emanating from both the Irish and Scottish councils, most of the planning behind cooperation between Scotland and Ireland originated in London with James, who was coordinating policy in all of his three kingdoms. While both the Irish and Scottish councils complied with James's directions, ultimately each was more concerned with their own respective realm. It was James who had a wider archipelagic, or "British," agenda. ${ }^{66}$ But these traditional, national perspectives are understandable. Each was jostling with the other in a new, unfamiliar, three-kingdoms context, and each sought to deal with its own problems. James, however, could see the wider implications of disorder in Ireland or Scotland for his plans for the outlying regions of his "impyre." It is within this archipelagic context that we need to consider James's plans for the Isles and his response to the military expedition led by Ochiltree in 1608, which resulted in the imprisonment in Edinburgh of most of the main Highland chiefs, and the 1609 expedition led by Bishop Knox, which aimed at encouraging cooperation with the chiefs.

On 10 March 1608 James had expressed his concern that the inhabitants of the Highlands and Isles continued in their lawlessness, thinking that the king had forgotten them. Consequently, he conveyed his resolve to deal with them properly. He would assert his royal authority via land and sea and declared that forces should meet at Islay on 1 June, to be joined by forces from Ireland, for "reduceing of the rebellious inhabitantis thairof to his Heynes obedyence and establischeing of religioun, peace, and justice." At the same time James was considering his options in relation to the north of Ireland, now "fred and disburdynit of the former rebellious and disobedient inhabitantis thairof." On account of this, he had taken "a verie princelie and good course, alswele for establischeing of religioun, justice, and civilitie within the saidis boundis, as for planting of coloneis thairin and distributing of the same boundis to lauchfull, ansuerable, and weill affected subjectis." Plantation in Ireland would "extend the reach of union" and secure James's vision of a united Britain. ${ }^{67}$ The outbreak of O'Doherty's rebellion threatened to throw

${ }^{65}$ Letter from the Edinburgh Council to Sir Arthur Chichester, 13 July 1608, RPCS, 8:512-13. The letter goes on to mention the 100 soldiers (although previous communication mentioned 200 soldiers) and their conditions of pay.

${ }^{66}$ Letter from the Lords and Irish Council to Sir Arthur Chichester, 2 June 1608, CSPI, 13:548-49. Canny (Making Ireland British, 195) argues that Chichester had "a responsibility" to further James's British endeavors, while the councils in Edinburgh and Dublin articulated a "new spirit of co-operation" around the time of the Flight of the Earls. They may well have done so, but this was due to political expediency rather than any deeper desire to consider local or national issues in a British context. The council in England, however, was clear in its prioritization of matters in the other two kingdoms. Orders sent to Chichester dated 2 June 1608 stated he was "not to divert any of the forces from the work he has in hand, in order to support the expedition intended against the Isles of Scotland." Irish affairs, the council asserted, were "of more consequence" than those of Scotland, "a country where the King is better assured of his contentment than he can be of Ireland."

${ }^{67}$ Proclamation concerning cooperation of Scottish and Irish forces, 10 March 1608, RPCS, 8:59-61; Proclamation concerning rebellious Islesmen, 10 March 1608, RPCS, 8:61; Proclamation for colonizing the north of Ireland with Scotsmen, 28 March 1609, RPCS, 8:267-68; see Paul J. McGinnis and Arthur H. Williamson, eds., The British Union: A Critical Edition and Translation of David Hume of Godscroft's "De Unione Insulae Britannicae" (Aldershot, 2002), 37, 217-23, esp. 217 n. 2, and 223. Hume advocated English settlements in the west Isles and Lochaber in order to civilize and thus 
the proverbial spanner in James's plan, so he initiated the steps necessary to coordinate efforts by all three realms in order to contain the situation.

Following a delay in the proposed timescale, James discussed the expedition to the Isles with his council in Edinburgh. The council had advised James that "the interpryse of the reduceing of the Yllandis of this kingdome to a perfyte and setled obedyence is verie necessar and expedient" and should continue as planned. ${ }^{68}$ James ordered all forces to meet at Islay on 1 July. However, the king stated his wish that the expedition should go ahead "by a moderat course, as mycht be least hurtfull." His previous assertion to treat with his Highland subjects rigorously had diluted somewhat and the king appeared to be urging a degree of caution. No doubt this leniency was a result of the recent actions of O'Doherty. Already facing rebellion in Ireland, James was reluctant to cause further unrest in the western Isles.

Naval support for Ochiltree's expedition to the Isles was sent from England. On 17 July 1608, Sir William St. John wrote to the council in Edinburgh informing them of his arrival in Loch Ryan with three ships for service in the Isles: The Advantage, which was manned and victualled for six months, The Moon, and Mercury ${ }^{69}$ Within a week, O'Doherty's rebellion was over, although a number of the main protagonists were still at large. According to the Privy Council's declaration of 2 August 1608, the rebellion's coming to an end was nothing short of a sign from God "manifesting his divyne providence and cair quhilk he hes . . . for the preservatioun and mantenance of all lauchfull authoriteis." ${ }^{\prime 70}$

Thus, events in one kingdom directly influenced James's plan of action elsewhere. By adopting a three-kingdoms perspective, James, to a greater degree than the Scottish and Irish councils, was able to adapt policy as circumstances dictated, and in this the king was successful. Ochiltree's expedition progressed as planned, and by the end of summer the following year Andrew Knox, bishop of the Isles, had reached a negotiated agreement with the Hebridean chiefs that subsequently became known as the Statutes of Iona. ${ }^{71}$

politicize the local inhabitants. This would ensure that the English saw these parts of the realm as their responsibility too, crucial in order to attain his vision of a united Britain. Indeed, as Hume urged James, "if you secure the farthest parts, there will be no region in which division may begin."

${ }^{68}$ Council order for the arrest of vessels to be employed in reducing the Isles, 21 May 1608, RPCS, 8:94-95; New issue of royal proclamation concerning the reduction of the Isles, 21 May 1608, RPCS, 8:95.

${ }^{69}$ Letter from Sir William St. John to the Edinburgh Council, 17 July 1608, RPCS, 8:514-15; Letter from Sir Arthur Chichester to the London Council, 16 July 1607, CSPI, 13:223. Prior to this, Captain St. John had been "employed on the coasts of Munster," but now, according to Chichester, he was "to ply up and down the channel and from the river of Strangford to that of Loghfoile . . . to amuse the rebels that perhaps they would lie still." See also Letter from the earl of Dunfermline concerning soldiers sent to Ireland including an account of payment, 13 July 1608, BL Add. MS, 32476, fols. 9-11.

${ }^{70}$ Proclamation for apprehension of Phelim Reogh MacDavid, 2 August 1608, RPCS, 8:139-41. James's "glorious and notable victorie over the wicked and detestable traytour O'Dogarty" was evidence of the "detestatioun" in which God "haldeth ungraitfull, disloyall, and trayterous subjectis, who, spending the course of thair naturall lyff in impietie, treasoun, and falshoode, make thair end and funerallis to be infamous, tragicall, and miserable."

${ }^{71}$ Andrew Stewart, third Lord Ochiltree, was a member of the Stewart family descended from Murdoch Stewart, duke of Albany, grandson of King Robert II. In 1534 his great-grandfather, Andrew Stewart, third Lord Avondale, had exchanged his barony of Avondale for that of Ochiltree in Ayrshire 


\section{THE STATUTES OF IONA: CONTEXT}

The Statutes of Iona, of which there are seven in total, have been regarded popularly as an attack on Gaelic culture. ${ }^{72}$ There is no doubt that some of the statutes sought to modify certain aspects of Gaelic society and behavior. Yet rather than attacking Gaelic culture, the aim of the statutes was to improve the living standards of the inhabitants of the region, maintain the position of the traditional elite, and assimilate the chiefs into wider Scottish society. ${ }^{73}$ Hence, both Macinnes and MacGregor have highlighted the statutes' concern with economic issues. For example, the suppression of sorning - the free extraction of food and drink by travelers and strangers-was necessary because it was "an intolerable burden" on Highland society. ${ }^{74}$ Instead, inns were to be established so that "straingeris, passingeris and utheris idill men" could purchase bed and board for "reasonable expensis." In addition there was an effort to limit trade in wines and whisky, as this would undermine the viability of the inns and hinder the socioeconomic improvement of Highland society. Other statutes were concerned with reform of religion, the provision of education for the eldest sons of the chiefs, the movement of itinerants and other "idill and sturdie beggaris" that were a further drain on the resources of Gaelic society, and the limitation of the use of firearms throughout the wider population. ${ }^{75}$ Another statute aimed at preventing the military element within clan society from continuing their activity in either Scotland or Ireland, thereby ensuring these clansmen did not obstruct the plantation of Ulster. James made it clear that this military class had two options: "tak thame selffis to industrie" or "face transportation and banishment." 76 Therefore, far from being, as Goodare has described them, "a temporary tidying-up operation," "paradoxical," and "in-

with Sir James Hamilton of Finnart, and later, in 1543, he was recognized as a lord of parliament with the title Lord Stewart of Ochiltree. Andrew, second Lord Ochiltree, had played an important role during the years of the reformation of religion in Scotland. Grandson of the second lord, Andrew, third Lord Ochiltree, was a nephew of James Stewart, earl of Arran, a favorite of James VI for a time. He was a member of the Privy Council, first Lord of the Bedchamber, governor of Edinburgh Castle, and General of the Ordnance. Andrew Knox was born in Renfrewshire, the second son of John Knox of Ranfurly in Kilbarchan parish. After studying at Glasgow University during the time of Andrew Melville, he was appointed minister of Lochwinnoch, Renfrewshire, in 1581, and then Paisley in 1585. During the 1590s he performed a number of services for James VI that resulted in his promotion to the bishopric of the Isles in 1605 . The following year Knox visited his diocese with a new seal depicting a bishop in an open boat. Thus, both Ochiltree and Knox had strong familial, political, and religious connections in the west and would have been familiar with crown reliance on the naval power of families in the region. See Margaret H. B. Sanderson, "Andrew Stewart, second Lord Ochiltree," ODNB; James Kirk, "Andrew Knox, bishop of Raphoe," ODNB; J. Balfour Paul, The Scots Peerage, 9 vols. (Edinburgh, 1909), 6:509-17.

${ }^{72}$ Macgregor, "Statutes of Iona," 138.

${ }^{73}$ Stevenson, Highland Warrior, 29-30; Macinnes, Clanship, 65. Macinnes asserts that the main impetus behind this legislation was "to educate the fine [clan elite] about their responsibilities as members of the Scottish landed classes."

${ }^{74}$ Macinnes, Clanship, 65-73; MacGregor, "Statutes of Iona," 138-50.

${ }^{75}$ Statutes of Iona, agreed 23 August 1609, registered 27 July 1610, RPCS, 9:27, 29. MacGregor ("Statutes of Iona," 150) suggests that the statute on firearms signified "the desire to preserve huntingvery much a traditional benchmark of behaviour and identity for the Gaelic elite-as an aristocratic monopoly."

${ }^{76}$ James's Instructions to the Lords Commissioners concerning the Isles, 9 February 1609, RPCS, 8:745-46; Macinnes, Clanship, 67. 
imical" to the power of the elite, MacGregor asserted that the statutes constituted a "coherent program, paramount being the economic condition of the Isles." In relation to clan society itself, Macinnes argued that the "privileged position" of the chiefs was "upheld and defined at the expense of their clansmen." more concerned with context than content, Maurice Lee argued that the statutes represented a "virtual abandonment of the colonization policy." ${ }^{78}$ While efforts to plant Lewis continued until 1610, to view the statutes, and indeed James VI and I's wider policy, in this light is to adopt a Scottish, rather than a British, perspective. But it is precisely this British, or archipelagic, context that is crucial to understanding both the statutes themselves and James's policy toward his three kingdoms.

Events in Ireland from September 1607 to July 1608 dramatically changed the wider context. The Flight of the Earls in September 1607 and the rebellion, and subsequent forfeiture, of Sir Cahir O'Doherty left large swaths of land in the north of Ireland vacant. With the removal of the native elite, James could contemplate plantation in Ulster on a grand scale in the north and west, while in the east Randal MacDonnell was already cooperating with the crown. But James was cautious regarding the development and implementation of plantation in both Ireland and the west of Scotland. Plantation could be considered for Ireland, but recent experience in Scotland did not bode well. At the same time, in light of longstanding traffic between the west of Scotland and the north of Ireland, further dispossession of the Hebridean elite could severely hamper efforts at plantation. Instead, a negotiated settlement with the native elite in Scotland would realize lasting and beneficial results, as we can see by tracing the events that led from Ochiltree's expedition to the statutes.

In spring 1608, around the time of the O'Doherty rebellion, "strategy toward the west remained coercive," but by the end of the year this had shifted, due to the quick suppression of the Irish revolt but also the outcome of Ochiltree's expedition to the Isles in the summer of that year. During the expedition, Ochiltree established garrisons in the castles of Dunivaig and Duart and apprehended a number of the leading chiefs, after which he brought them back to the Lowlands and placed them in ward. ${ }^{79}$ By the end of the year, James had set up a commission for the Isles whose aim was "to reasoun, advise, consult and deliberat upoun the best, reddiest, and most spedie meanis how that bipast savaigenes and barbaritie whiche hes bene of so long continewance in these boundis may be ruted oute, and that civilitie, oure obedyence, and trew religioun (the onlie meane to preserve

\footnotetext{
${ }^{77}$ Goodare, "Statutes of Iona," 41, 51, 53; MacGregor, "Statutes of Iona," 113; Macinnes, Clanship, $65-66$.

${ }^{78}$ Lee, Government by Pen, 79-80; MacGregor, "Statutes of Iona," 112-13; Goodare, "Statutes of Iona," $47-48$.

${ }^{79}$ Report of Lord Ochiltree to the Edinburgh Council, 5 October 1608, RPCS, 8:173-75; Letter from the earl of Argyll to the Edinburgh Council, 6 October 1608, RPCS, 8:741-42; Council minute, 6 November 1608, RPCS, 8:742. Hector Maclean of Duart, Lauchlan MacLean, brother of Hector, Allan MacLean, son of MacLean of Ardgowan, Neil MacIlduy and Neil MacRory, dependents of MacLean of Duart, were warded in Dumbarton Castle; Donald Gorm of Sleat and Donald MacAllan MacIan, captain of the Clanranald, were warded in Blackness Castle; Alexander MacLeod, brother of Rory MacLeod of Dunvegan and Harris, was warded in the Tolbooth in Edinburgh. Angus MacDonald of Clan Donald South was allowed to remain at liberty with a promise he would appear before the council on 15 November. Rory MacLeod of Dunvegan and Harris was yet to come in.
} 
bothe), may be planted." 80 While the king's "Instructions" to the Commission for the Isles of December 1608 "contemplated the expropriation or banishment of at least some of the indigenous elite," MacGregor argued, this "diplomatic process yielded signs of encouragement." The instructions asserted that as the principal chiefs of the Isles were now in ward "thair can not be offerrit ony better occasioun of capitulatioun with that sorte of people." The "present oportunitye" was "very remarkable," and James went on to state that he was "unwilling to extermine, yea skairse to transplant, the inhabitantis of the same, bot upoun a just caus." 81

A period of negotiation followed in early 1609 between the commissioners and the Islesmen, and, although some agreement was reached, it was not enough. In spring 1609 Knox went to London to discuss matters with the king, and in June 1609 he received a commission to undertake another expedition to the Isles to survey crown lands and bring in the chiefs that "are not yitt enterit" by offering "libertie of saulff comeing and going without trouble and impediment, that so by these means thay may be induceit to come in and mak assurance of all the offeris that ar maid in thair name." The chiefs currently imprisoned were to be released "upoun sufficient pledgeis and bandis takin of foirfeyte of thair whole landis yf thay do not observe every thing that is required of thame." Knox subsequently held court in August 1609 at Iona, where the statutes were negotiated. He then appeared briefly before the council in September, after which he made straight for London to present the outcome of his expedition to the king. In May 1610 James asked the council to proceed with the registration of the statutes, which finally took place in July $1610 .{ }^{82}$

In order to support his view that the statutes represented a "temporary tidyingup operation" rather than "a solution," Goodare pointed to the lack of communication concerning them that followed Knox's submission to the king of the statutes through to their registration, in the period between September 1609 and July 1610. This was the result of the statutes, he continues, being "cast into oblivion." In contrast, MacGregor put forward a radically different interpretation. He afforded Knox a pivotal role in advancing crown policy during this period from August 1608 to August 1609, when it shifted from "colonisation or expropriation to . . . an unfolding scenario where chiefs were not merely secure if they co-operated, but also enlisted to act on government's behalf." Thus, the statutes were much more than a mere sticking plaster. Indeed, according to MacGregor "Knox had hit the jackpot" and "far from departing from his brief, he had fulfilled it beyond anyone's expectations . . . the delay represents, not the consigning of the statutes to oblivion and irrelevance, but their imminent presence." ${ }^{83}$ Knox had achieved more than James had hoped for. Numerous attempts had been made

\footnotetext{
${ }^{80}$ Royal commission to certain members of the Edinburgh Council, 6 February 1609, RPCS, 8: $742-43$.

${ }^{81}$ James's Instructions to the Lords Commissioners concerning the Isles, 6 February 1609, RPCS, 8:745; MacGregor, "Statutes of Iona," 113-14.

${ }^{82}$ Royal letter concerning the Isles, 27 June 1609 , RPCS, 8:752-53; Royal letter to the Edinburgh Council, 8 May 1610, RPCS, 9:16-18; Bond of Obedience from the Island chiefs to James, agreed 24 August 1609, registered 27 July 1610, RPCS, 9:24-26; Statutes of Iona, agreed 23 August 1609, registered 27 July 1610, RPCS, 9:26-30; Goodare, "Statutes of Iona," 37-38.

${ }^{83}$ Goodare, "Statutes of Iona," 41-42; MacGregor, "Statutes of Iona," 113, 116, 119-20.
} 
previously to reach a workable agreement with the Highland chiefs, but they had come to nothing. Now James could proceed realistically along the lines of cooperation; but he needed time to reconsider how to implement this policy further.

James wanted to ensure that the implementation of policy in both regions would be mutually beneficial. A negotiated agreement with the Hebridean elite would help secure the success of his Ulster venture by limiting dislocation and curtailing unrest, while plantation on such a scale as that planned for Ulster would ensure no refuge could be offered to lawless Highlanders and Islesmen. There was no blanket policy for Gaeldom. ${ }^{84}$ Instead, responsive to events as they happened and ready to adapt as circumstances dictated, James progressed with a number of different strategies for different parts of his kingdoms. ${ }^{85}$ The delay, therefore, between Knox's submission of the statutes in September 1609 and their registration in July 1610, was not the result of "indecision" or "neglect" but caution. ${ }^{86}$

Nor did James register the statutes "begrudgingly, through gritted teeth and double-negatives." ${ }^{87}$ Instead, the agreement that Knox reached with the Hebridean elite, although unexpected, was very welcome, and James was optimistic about pursuing a negotiated settlement. Extirpation and plantation had been on the agenda for some time but had been envisaged for the most barbaric inhabitants who resolutely refused to submit to royal authority ${ }^{88}$ James had always hoped to make his Scottish Gaelic subjects obedient to his authority, yet ongoing resistance had encouraged James to take a firmer stance, implementing plantation in Lewis and advocating further plantation in the western Isles. ${ }^{89}$ Although James would

\footnotetext{
${ }^{84}$ Macinnes, Clanship, 57-59, discusses social and legal differences between Gaelic Scotland and Gaelic Ireland.

${ }^{85}$ Allan Macinnes, "Making the Plantations British, 1603-38," in Frontiers and the Writing of History, 1500-1850, ed. Steven G. Ellis and Raingard Esser (Laatzen: Wehrhahn, 2006), 95-125, 104.

${ }^{86}$ It is, perhaps, more than a coincidence that in May 1610, when James asked council to proceed with registration of the statutes, land in Ulster was finally ready to be handed over to new owners. Having been preoccupied with affairs in Ireland, James could now turn his attention back to the Isles.

${ }^{87}$ MacGregor, "Statutes of Iona," 120.

${ }^{88}$ James employed the policy of transplantation elsewhere in his three kingdoms. For the transplantation of the Grahams from "the mid center of the hole Yland under our impyre" to Ireland, see Letter from the London Council to Sir Arthur Chichester and the Irish Council, 30 April 1606, CSPI, 12: 462; Petition of Grahams, n.d. [1606?], CSPI, 13:50; Letter from Sir Arthur Chichester to the London Council, 21 February 1607, CSPI, 13:118; Letter from Sir Arthur Chichester and the Irish Council to the London Council, 20 April 1607, CSPI, 13:140; Letter from Sir Arthur Chichester to the London Council, 23 June 1607, CSPI, 13:198; Letter from James to Sir Arthur Chichester, 16 July 1607, CSPI, 13:222; Letter from Sir Arthur Chichester to the London Council, 4 August 1607, CSPI, 13: 245; Letter from Sir Arthur Chichester to the London Council, 11 April 1608, CSPI, 13:471; Abstracts of letter from Sir Arthur Chichester to the London Council, 4 July 1609, CSPI, 14:251. Others were sent to the Netherlands to fight; see Ohlmeyer, "'Civilizinge of those rude parts," 132.

${ }^{89}$ Colin Kidd (British Identities before Nationalism: Ethnicity and Nationhood in the Atlantic World, 1600-1800 [Cambridge, 1999], 123-45) discusses the problematic and paradoxical attitudes of the crown, the kirk, and wider Lowland society toward Gaelic Scotland. Indeed, Kidd argues that this region "which in practice constituted the periphery of the Scottish nation . . . continued . . . to define Scotland's identity and the historical legitimacy of its institutions" (127), while James VI "showed no reluctance to base his political theories on the ancient Scots" of the west. Thus, although Lowland society refused to reject the origins of its Gaelic past, it continued to express hostility toward Gaelic society, language and culture. See also Roger A. Mason, "Civil Society and the Celts: Hector Boece, George Buchanan and the Ancient Scottish Past," in Scottish History: The Power of the Past, ed. Edward J. Cowan and Richard J. Finlay (Edinburgh, 2002), 95-119; Macinnes, British Revolution, 8-24, 40-41, $54-62$.
} 
pursue plantation in Ireland, this was a response to the opportunity presented by the Flight of the Earls and the O'Doherty rebellion. In December 1608 he had counseled the commissioners of the Isles to "be moir cairfull for recovery of one member of your awne body almost rottin and decayed" than for a "parcell of that whiche, howevir pertening to this estate, yitt is no parte of this kingdome." $" 90$ Reform of the Hebridean elite would see them integrated into wider Scottish society both politically and, as the statutes emphasized, economically. ${ }^{91}$

Through his negotiations with the chiefs, Knox offered James the opportunity to achieve what a few years previously had appeared unobtainable: the integration of his Highland subjects into Scottish society. ${ }^{92}$ In May 1610 James acknowledged that "the said Ilesmen, in a court haldin be the said Bischop at Icolmakill, have bound thameselffis to performe dew obedience to us and our authoritie, and to keip peace and quietnes in the cuntrey." ${ }^{\prime 3}$ But the process that led the chiefs to this position, much like the development of crown policy, was a long and continuous one, and its roots lie back in 1607 and 1608. Considering the wider context, it is not surprising that the chiefs reacted in the way they did and agreed to the proposals put forward by Knox. In recent years they had witnessed the crown's repeated attempts at the Lewis plantation despite opposition from the MacLeods, while the Clan Donald South faced displacement as the earl of Argyll acquired legal rights to their lands. Coming to terms with the political situation in Scotland meant acknowledging that crown intervention was not going to go away. Although the west Highlands and Isles of Scotland had a history of royal intervention followed by some degree of accommodation, events in Ireland raised the possibility of an altogether different scenario. When the native elite in Ireland heard rumors of impending crown action, they took leave and headed for the continent. Meanwhile, in Scotland the crown had made its attitude quite clear; the wording of the commission given to Knox in 1609 was far from subtle: use "all kynd of hostilitie yf thay continew rebellious and dissobedyent." ${ }^{" 4}$ Ongoing opposition to the crown looked distinctly unappealing.

While the fate of O'Neill and O'Donnell loomed over them, the Islesmen could consider the example of Randal MacDonnell and recognize the benefits that came from cooperation with the crown. Thus, since their alternatives were to be forced from their land by the earl of Argyll, who had received a commission to extirpate the Clan Donald, or to see their patrimonial lands planted like Lewis or Ulster, the Highland elite were amenable and open to negotiation with Knox. Macinnes's reasoning that the "aversion of chiefs and leading clan gentry to collaborate with Ochiltree and Knox was ... remedied after brief gaoling in the Lowlands" is

\footnotetext{
${ }^{90}$ James's Instructions to the Lords Commissioners concerning the Isles, 6 February 1609, RPCS, $8: 745$.

${ }^{91}$ Macinnes, Clanship, ix, 65-73; MacGregor, "Statutes of Iona," 138-58, esp. 156.

${ }^{92}$ Knox was later rewarded with the appointment to the bishopric of Raphoe in Donegal on 6-7 May 1610, again emphasizing James's three-kingdoms perspective. If Knox could achieve such results in the west Highlands and Isles, he would be a useful individual to have operating in the north of Ireland during the plantation. See Ohlmeyer, "Civilizinge of those rude parts," 135. Ochiltree became an undertaker in the plantation of Ulster, and was granted lands within Tyrone by James VI in 1610. His son, Andrew Stewart, was created Baron Castlestewart by James in 1619.

${ }^{93}$ Letter from James to the Edinburgh Council concerning the Isles, 8 May 1610, RPCS, 9:18.

${ }^{94}$ Commission to Andrew Knox, Bishop of the Isles, 30 June 1609, RPCS, 8:756; McCavitt, Flight of the Earls.
} 
perhaps too simplistic. So too is MacGregor's explanation that a "constant factor conditioning the behavior of the Hebridean elite since spring 1608 must have been fear." 95 Certainly these were contributing factors, as was the fact that both Ochiltree and Knox were from west coast families. Of utmost importance, however, was the realization on the part of Highland chiefs that ongoing resistance to crown policy would reap further ruthless, coercive government action. Because the Highland chiefs were ready to negotiate terms and acknowledge royal authority, in the resulting Statutes of Iona James achieved what he had originally intended: not the removal of the clan elite but instead their assimilation into Scottish landed society. ${ }^{96}$

Initial progress toward this assimilation made little headway until the suppression of the Clan Donald South rebellion in 1615. In response, the Privy Council issued a legislative package in 1616-17 that redefined and reinforced many aspects of the statutes introduced through individual contracts with clan chiefs. Largely identified with the eighteenth century, the beginnings of a commercialized society emerged in the Highlands in the early seventeenth century. However, for clan society there were unforeseen by-products of the statutes. The obligation on chiefs to appear annually before council and give account of themselves and their clan meant extended visits to the Lowlands. This resulted in absenteeism and accumulation of debt, while indebtedness encouraged dependence on lawyers to manage the chiefs' financial affairs. Within the Highland region itself, the shift from oral contracts to written leases clearly defined the terms of landholding. As chiefs became more commercially oriented, land came to be viewed not as the patrimony of the clan but as an economic resource to be exploited. Chiefs raised rents; they no longer viewed tenants as clansmen and increasingly resorted to evictions of those tenants who could not meet their demands. In the [Gaelic] oral tradition this shirking of the traditional obligations of clan society was criticized.

The repercussions of the Statutes of Iona, therefore, were more far-reaching than James could have envisaged. They had offered a means by which he could eliminate certain characteristics of clan society while simultaneously bringing the Highlands more into line with the rest of Scotland. Admittedly, throughout the seventeenth century absentee monarchs became less concerned with implementing reform in the region, but, in forging this agreement with the Hebridean elite, James, far from being "the hammer of the Highlands," showed himself to be a traditional Stuart monarch, inclined rather more toward conciliation than retribution. ${ }^{97}$

\footnotetext{
${ }^{95}$ Macinnes, "Making the Plantations British, 1603-38," 104; MacGregor, "Statutes of Iona," 115.

${ }^{96}$ Macinnes, "Making the Plantations British, 1603-38," 105.

${ }^{97}$ Macinnes, Clanship, 56-81; Bardachd Chloinn Ghill-Eeathain, Eachann Bacach and Other Maclean Poets, ed. Colm O. O'Baoill (Edinburgh, 1979); Kidd, British Identities before Nationalism, 127; Mason, "Renaissance and Reformation," 139.
} 